Published on Reviews in History (https://reviews.history.ac.uk)

\title{
Lincoln's Sense of Humor
}

Review Number: 2255

Publish date: Thursday, 21 June, 2018

Author: Richard Carwardine

ISBN: 978-0809336142

Date of Publication: 2017

Price: $£ 24.95$

Pages: 168pp.

Publisher: Southern Illinois University Press

Publisher url: http://siupress.com/books/978-0-8093-3614-2

Place of Publication: Carbondale

Reviewer: Graham Peck

Richard Carwardine, an acclaimed Lincoln biographer and coeditor of a highly original book of essays on Lincoln's worldwide image, has now turned his attention to the entertaining subject of Lincoln's humor.

Lincoln was well known for his levity, fund of anecdotes, and enjoyment of dirty stories, and Carwardine seeks to paint a portrait of the laughing Lincoln in order to deepen appreciation for humor's essential role 'in the thought and practice of both man and president' (p. 6). The study is wide-ranging, including an extensive examination of the sources, types, and subjects of Lincoln's humor, along with its purpose, functions, and effects. Along the way, Carwardine roots Lincoln's humor in its frontier origins and judiciously assesses humor's role in Lincoln's psychology. But his most impressive contribution is to connect the laughing Lincoln to the fate of the country. He explains how Lincoln used humor to shape relations with others, advance his career, and preserve the nation.

Lincoln, like most other human beings, thought and acted differently as he matured, and Carwardine traces corresponding maturation in Lincoln's use of humor. Hilarity was in his genes and upbringing. Lincoln's cousin Dennis F. Hanks recalled that Thomas Lincoln 'could beat his son telling a story - cracking a joke', and the young Lincoln eagerly participated in fun-loving camaraderie (p. 36). He began developing skills as a raconteur as a boy, becoming well-known and well-liked for witticisms and stories. He also displayed a pronounced gift for mimicry, which displayed his theatrical tendencies and incredibly retentive memory. Yet Lincoln also had a sharp-elbowed tendency to use humor as a way of taking revenge or punishing a rival. This trait was evident before he left Indiana, and it revealed itself frequently during Illinois' bitter political battles of the 1830s and 1840s. His well-known and embarrassing conflict with Democratic state auditor James Shields, which very nearly resulted in a duel, flowed from Lincoln's anonymous, colorful, and deeply insulting portrayal of Shields in Springfield's Sangamo Journal. Cruelty was the dark side of his wit, one that he tempered as his judgment improved, career progressed, and skill deploying humor deepened.

Generally, he put his humor to good uses. As a congressman, he facilitated relations with men on both sides of the political aisle by a 'conciliatory use' of stories and jokes, and he became known 'as the champion story-teller of the Capitol' (p. 24). When he returned to Springfield in the early 1850s and focused on his law practice, he brought juries to his side with bonhomie and lively use of anecdotes to make his point. It was this particular power of humor - its capacity to cut through debate and appeal to shared experience, common 
sense, and decency - that would prove to be of enormous significance for Lincoln's political career after 1854, when the prospect of slavery's expansion into free territories precipitated his return to politics. Corralling his humor, he began using it primarily to make a point. This shift was necessitated by the moral significance of slavery, which to Lincoln was no joking matter. According to Carwardine, Lincoln adopted 'an earnest mien' in his speeches after 1854, seeking to persuade his hearers of slavery's gravity (p. 26). Lincoln used his wit to rebut opposing arguments and to present himself as likable, but maintained a 'fundamental mood of seriousness' (p. 29). As president, this orientation did not change. Lincoln stripped humor from his public addresses even as it became more essential to his private emotional stability. The old and careworn Lincoln so evident in photographs truly reflected the changes in the man. His humor had become carefully guarded.

By that time, however, it had also become strongly harnessed to his moral sense. Carwardine contends that Lincoln's well-known appreciation for the satire of newspaperman David Ross Locke, who lampooned proslavery Unionists during the war, reveals 'the moral springs' of Lincoln's humor (p. 5). Locke was an antislavery Ohioian who pitted himself against slavery by creating a fictional Democratic preacher named Petroleum Vesuvius Nasby, who spewed an 'antiblack, proslavery peace gospel' from his pulpit (p. 74). Locke's portrait was memorable and unforgiving. Nasby was a stupid, illiterate, greedy, and hypocritical Democrat, which explained his ugly racism and unapologetic defense of slavery. In one characteristic outburst, Nasby used the Bible to prove 'that niggers is Skriptoorally slaves, and ... the Fugitive Slave Law to be skriptooral', but observed that the 'rest uv the Bible we consider figgerative, and pay no attenshun to, whatever' (pp. 76-7). Meanwhile, having 'unfalterin trust in the rychusnis uv the Suthrin coz', Nasby urged the 'mobbing uv Methodis, Presbyterin, Luthrin, Brethrin and uther hetrodox churchis' (p. 76). His proslavery Christianity reflected 'a holesum prejoodis agin evrything black', and when judging how 'Dimocrisy' could best appeal to voters, Nasby concluded that 'Nigger is all the capital we hev left' (pp. 76-7). All in all, Nasby was a searing indictment of the northern Democratic Party, and Locke used him to lay bare the moral purpose of the war: preserving the Union, and with it democracy, Christianity, and the ideal of human equality.

Lincoln was very likely Locke's biggest fan. Recalling Lincoln reading from the Nasby letters 'with infinite zest, while his melancholy features grew bright', Massachusetts senator Charles Sumner deemed Locke the president's 'favorite humorist' (p. 79). Sumner's experience was hardly atypical. Lincoln kept Locke's pamphlets in his office and frequently read them to visitors, including to leading politicians and members of his cabinet who came on urgent business. Eager to speak with Locke, the president invited him to Washington for a chat, and offered him any position in the government for which he was qualified. Perhaps most remarkably, he twice declared admiringly that for 'the genius to write these things I would gladly give up my office' (p. 79). From the author of the Gettysburg Address, this was astonishing praise.

Carwardine explains this praise by reference to Lincoln's 'righteous mirth' and 'just laughter' (p. 67). If humor anchored Lincoln's personality, as Lincoln often claimed and Carwardine persuasively contends, then it is hardly surprising that Lincoln celebrated humorists who expressed his most deeply held values. Locke did exactly this. He revealed slavery's power to warp human sensibilities, especially the sacrifice of justice to greed. While Lincoln expressed his hatred of slavery using humor and logic, and in his greatest speeches profound prose poetry, Locke's genius was to communicate plainly through Nasby, a vile creation whose every utterance violated norms of shared experience, common sense, and decency. In Nasby, Northerners saw what they did not wish to be. Consequently, in Locke, Lincoln found a powerful ally in the cause of freedom, Union, and justice.

Lincoln's love of Locke helps Carwardine place Lincoln near the vanguard of northern racial justice. 'Racial egalitarians were rare among white people of his era', writes Carwardine, and 'Lincoln himself was not one of this group' (p. 82). But Lincoln tirelessly defended blacks as humans, and correspondingly insisted that all humans possessed inalienable rights to life, liberty, and the pursuit of happiness. Judged by Carwardine, Lincoln's 'racial ideas' revealed a 'chasm' between Republicans and northern Democrats, who were led by Lincoln's great rival, Illinois Senator Stephen A. Douglas (p. 84). The chasm widened immeasurably during 
the war, because Lincoln as president ultimately pushed for black equality on many fronts, something unimaginably repugnant to Douglas and his northern Democratic followers. Lincoln's progressive course, Carwardine concludes, 'gave a keener edge to his reading of Nasby and encourages the proposition that in a small way Locke assisted in his radicalization' (p. 84). It is a creative reading of Lincoln the radical.

Yet Lincoln's humor also posed political risk. As president, he policed his use of humor to prevent excessive levity from undermining his reputation and sabotaging his leadership. Nevertheless, his private expressions of humor were well known to Americans, and consequently shaped political debate. Supporters presented him as a 'genial' president whose jokes reflected his wisdom, enabling him to cope with challenges and communicate with the common folk (p. 103). As a New York lawyer put it, Lincoln's storytelling explained why 'the people can understand him so well, and why the politicians can not comprehend him at all' ( $p$. 105). By contrast, Lincoln's political opponents lambasted him as a buffoon. They exploited his reputation for crudeness, arguing that it 'exposed a disabling lack of gravitas and principal', reflected his incompetence, and deadened his sympathy for the 'mangled corpses of our dead soldiers' and their families (pp. 108, 111). All of these critiques intensified in the election of 1864. Republicans who wanted a new nominee arraigned themselves against a president who enjoyed a 'smutty story', while Democrats lacerated the 'cold-blooded joker' who could barely 'spare a minute from Joe Miller's jest book' to consider the carnage he had unleashed upon the nation (pp. 113, 115-16). To spread that idea, Democrats concocted propaganda that Lincoln had requested the singing of 'a Negro song' while driving through the Antietam battlefield in 1862 (p. 116). Frequently repeating this charge, they sought to tie his 'perverted racial appetites' and grotesque humor to his disdain for the dead and unsuitability for office (p. 117). A Democratic campaign song emphasized the same connection: 'Honest Old Abe was a queer old coon, / Joked with a nigger and play'd the buffoon' (p. 117). Ultimately, Lincoln's re-election hinged far more on the success of the Union armies than on any other factor, but Carwardine shows that his humor was fraught with political implications. Since the Civil War, Americans have remembered Lincoln's presidential humor as 'wholly positive and benign', but during his lifetime that was far from true (p. 122). In the president, Democrats perceived not a wit, but a witless.

One of the joys of reading the book is proximity to Lincoln. The experience is surprisingly intimate because the reader relives the experiences of so many people who encountered Lincoln. They were his companions, and shared part of his life, and their recollections enable us to share it too. We learn that he prayed as a boy 'that God would put stockings on the feet of chickens in winter', a cheeky absurdity that, like his mimicry of backwoods Baptist preachers, gratified his howling peers (p. 9). In 1831, in Sangamo Town, a log stripped of bark became polished, and known as 'Abe's log', because 'the boys on the log would whoop and roll off' when Lincoln climaxed a joke (p. 11). In the mid-1840s, Lincoln's law clerk Gibson Harris wrote to his friends that 'I wish you co[uld] be in the office about two hours, to hear Lincoln tell his tales and anecdotes ... I think you would laugh yourself well in that length of time'. Often 'convulsed with laughter', Harris had 'seen a dozen or more, with their hands on their sides[,] their heads thrown back, their mouths open, and the tears coursing down their cheeks, laughing as if they would die, at some of Lincoln's jokes' (p. 16). In the late 1840s, when dining at Mrs. Sprigg's Washington boardinghouse, Lincoln had the same effect on fellow congressmen and other diners. Samuel Busey recalled that Lincoln would 'lay down his knife and fork, place his elbows upon the table, rest his face between his hands, and begin with the words "that reminds me", and proceed. Everybody prepared for the explosion sure to follow' (p. 24). And before he departed Springfield for the presidency, a New York Herald reporter observed that his language was "pervaded by a humorousness, and, at times, a grotesque joviality, that will always please. I think it would be hard to find one who tells better jokes, enjoys them better and laughs oftener, than Abraham Lincoln' (p. 32). By book's end, most readers will want their own two hours with this most 'genial man of the people' (p. 103).

Carwardine's insights are partly the fruit of the remarkable advances in Lincoln scholarship over the past 20 years. He draws intensively on Don and Virginia Fehrenbacher's Recollected Words of Abraham Lincoln, Douglas L. Wilson, Rodney O. Davis, and Terry Wilson's Herndon's Informants: Letters, Interviews, and Statements about Abraham Lincoln, Paul M. Zall's Abe Lincoln's Legacy of Laughter: Humorous Stories by and about Abraham Lincoln 
, Michael Burlingame's two-volume Abraham Lincoln: A Life (1), and Burlingame's even more encyclopedic unedited online edition. Collectively, these works and others have greatly improved the accessibility of primary sources on Lincoln, and Carwardine mines them and an exhaustive array of other sources with consummate skill to ferret out Lincoln's laughs. He does so primarily to shed light on Lincoln's life, but in so doing illuminates important characteristics of American culture. Reading this book is a reminder of how gifted historians stitch together the remnants of a lost past to deepen our understanding of the human condition. It is a little gem carved by the hand of a master.

\section{Notes}

1. Don and Virginia Fehrenbacher, Recollected Words of Abraham Lincoln (Stanford, CA, 1996); Douglas L. Wilson, Rodney O. Davis, and Terry Wilson, Herndon's Informants: Letters, Interviews, and Statements about Abraham Lincoln (Champaign, IL, 1998); Paul M. Zall, Abe Lincoln's Legacy of Laughter: Humorous Stories by and about Abraham Lincoln (Knoxville, TN, 2007); Michael Burlingame, Abraham Lincoln: A Life (Baltimore, MD, 2008). Back to (1)

The author accepts this review. He appreciates the scrupulous care with which the reviewer has read and contextualised the book, and echoes his tribute to the wealth of recent scholarship on which the author has been able to draw.

\section{Other reviews:}

Wall Street Journal https://www.wsj.com/articles/lincoln-wasnt-handsome-but-he-had-a-great-sense-of-humor-1518377892 [2]

New Yorker https://www.newyorker.com/cartoons/bob-mankoff/lincolns-smile [3]

Source URL:https://reviews.history.ac.uk/review/2255

\section{Links}

[1] https://reviews.history.ac.uk/item/297361 [2] https://www.wsj.com/articles/lincoln-wasnt-handsome-buthe-had-a-great-sense-of-humor-1518377892 [3] https://www.newyorker.com/cartoons/bob-mankoff/lincolnssmile 